\title{
Comparing survival and size of resprouts and planted trees for post-fire forest restoration in central Portugal
}

\author{
Francisco Moreira*, Filipe Catry, Tito Lopes, Miguel N. Bugalho, Francisco Rego \\ Centro de Ecologia Aplicada “Prof. Baeta Neves”, Instituto Superior de Agronomia, Universidade Técnica de Lisboa, Tapada da Ajuda, 1349-017 Lisbon, Portugal
}

\section{A R T I C L E I N F O}

\section{Article history:}

Received 18 August 2008

Received in revised form 7 December 2008

Accepted 24 December 2008

\section{Keywords:}

Sprouting

Mediterranean

Fire

Passive restoration

Assisted restoration

\begin{abstract}
A B S T R A C T
The post-fire restoration of burned forests in the Mediterranean basin usually involves planting or direct seeding, often neglecting the use of natural regeneration through basal resprouting. This study compared the survival and size of planted and resprouted Fraxinus angustifolia (narrowleaf ash) and Quercus faginea (Portuguese oak) in a burned area in central Portugal, after a 20-22-month growing period. Adult ash and oak trees were burned in a wildfire in September 2003. The survival and height of resprouting suckers were assessed 21 months after fire. Seedlings coming from nurseries were planted in the same area during January to March, both in 2004 and 2005, and their survival and height were assessed 20-22 months after planting. Survival was higher in resprouts than in planted trees in the case of oak $(98 \%$ against $77 \%$ and $67 \%$, respectively, for trees planted in 2004 and 2005) but not for ash (100\% against $87 \%$ and 97\%). Plant height was much higher in resprouts than in planted trees (4-5 times higher in oak; 2-3.8 times higher in ash), and a similar pattern was found for basal diameter (3.5-4.5 times higher in oak; 3-5 times higher in ash). The results suggest that using natural regeneration through resprouting may be a cheaper and more effective technique than planting to restore burned forests with a large proportion of resprouter species, as is the case of many Mediterranean broadleaved forests.
\end{abstract}

(ㄷ) 2009 Elsevier B.V. All rights reserved.

\section{Introduction}

Every year about half a million hectares of forests and shrublands are burned in southern European countries. The post-fire rehabilitation of these areas is a major task for national and regional governments, as well as for forest managers (Hüttl and Gerwin, 2007), but there is still a significant lack of knowledge on the best management techniques to use. In many situations burned trees are felled (salvage logging). After clear felling, there is strong political pressure to actively reforest burned areas in the Mediterranean region and this has been a common practice since the late 19th century, mainly in conifer forests (Pausas et al., 2004b; Vallejo, 2005). As an example, following the 2006 wildfires in Galicia (Spain), which burned 150,000 ha of land, reforestation has been considered a restoration priority (Amil, 2007). In the case of Portugal, policies for the reforestation of burned forests have been common (Carvalho Mendes, 2006). All these reforestation efforts are assumed to be done by means of active restoration techniques such as plantation or direct seeding, each with its advantages and drawbacks (e.g. Duyea, 2000; Lamb and Gilmour, 2003; Vallejo et al., 2006).

\footnotetext{
* Corresponding author. Tel.: +351 213616080; fax: +351 213623493

E-mail address: fmoreira@isa.utl.pt (F. Moreira).
}

In contrast, taking advantage of passive restoration, by protecting areas from further disturbances and allowing natural colonization, regrowth and successional processes (Lamb and Gilmour, 2003; Vallejo et al., 2006), has not been frequently used as a restoration technique in the Mediterranean context. However, it usually entails a lower financial cost, even if some degree of intervention to assist this natural regeneration (either from seeds or resprouts) is used (e.g. Holz and Placci, 2005; Vallejo et al., 2006). Conflicts between these two approaches (active or passive) for restoration are possible, particularly if governments subsidise active restoration in areas where natural regeneration is occurring.

Passive post-fire restoration may profit from regeneration from seeds (Pausas et al., 2004a; Holz and Placci, 2005) or from resprouting of burned trees and stumps (mostly basal resprouting) (Espelta et al., 2003). Although there are several studies comparing the effectiveness of different restoration techniques, in terms of tree seedling survival and growth, they mostly compare planting and seeding methods (either natural seeding or direct seeding) (Lockhart et al., 2003; Ammer and Mosland, 2007; Dostálek et al., 2007), but not natural regeneration from basal resprouting of burned trees. However, the use of plant resprouting ability is already acknowledged as a powerful and pragmatic tool to restore some ecosystems (Wyant et al., 1995), e.g. the Atlantic rainforests of Brazil (Simões and Marques, 2007). In fact, resprouts have many 
potential advantages over seedlings or planted trees because they have an already established root system and high stored energy reserves, which may confer greater chances of plant survival and recovery (e.g. Bond and van Wilgen, 1996; Simões and Marques, 2007).

In the summer of 2003, a wildfire occurred in a protected area in central Portugal (Tapada de Mafra). A post-fire monitoring programme of tree survival and post-fire responses was started in the winter following the fire. At the same time, the managers of this area decided to reforest part of the area by planting some species, including two - Fraxinus angustifolia (narrowleaf ash) and Quercus faginea (Portuguese oak) - also being monitored for post-fire resprouting. This provided an opportunity to compare survival and growth of planted and resprouted trees. The aim of this study is to compare the survival and size of resprouting shoots, 21 months after a fire, with the ones of planted seedlings with a similar growing period (20-22 months) in the field.

\section{Methods}

\subsection{Study area}

The study area ( 885 ha) is located in central west Portugal $\left(38^{\circ} 58^{\prime} 30^{\prime \prime} \mathrm{N}, 9^{\circ} 15^{\prime} 52^{\prime \prime} \mathrm{W}\right), 8 \mathrm{~km}$ far from the sea. The altitude ranges between 100 and $350 \mathrm{~m}$ and the soils are humic cambisols derived from sandstone. The mean annual precipitation is $798 \mathrm{~mm}$ and the mean annual temperature is $14.6^{\circ} \mathrm{C}$. The vegetation is mainly dominated by forests, composed by broadleaved and coniferous species (dominant species include Quercus faginea, Quercus suber, Quercus coccifera, Pinus pinaster and Pinus pinea), and by shrublands dominated by Erica spp. and Ulex spp. Ungulate populations of deer (Dama dama and Cervus elaphus) and wild boar (Sus scrofa) occur at densities of $0.4 \mathrm{deer} / \mathrm{ha}$ and 0.2 wild boar/ha. The area was severely affected by a wildfire in September 2003 that burned ca. 70\% of the Tapada. During the study period the weather conditions were much worse in 2004 and 2005, the driest and lowest rainfall years since 1931, than in 2006, which was considered a normal year. Yearly rainfall data from a local weather station yielded $438 \mathrm{~mm}, 608 \mathrm{~mm}$, $1024 \mathrm{~mm}$, and 623 mm, respectively, for 2004, 2005, 2006 and 2007.

\subsection{Characterising survival and growth of trees resprouting from the base of dead stems}

Three months after the fire (December 2003), the study area was divided into a regular grid of $500 \mathrm{~m} \times 500 \mathrm{~m}$, and 20 points (centers of each grid square) were randomly selected in the burned area as the initial point for field transects. For some cases, the initial location of transects was changed because they were located in areas without trees. Each transect was ca. $100 \mathrm{~m}$ long and $20 \mathrm{~m}$ wide, and the burned trees found along it were individually tagged, identified to species level, and measured (total height and diameter at breast height). To prevent the impact of wild herbivores on tree regeneration (basal resprouting) some trees were protected from browsing using individual tree protectors (woven-wire fencing with a height of $1.5-1.8 \mathrm{~m}$, and a mesh size of $5 \mathrm{~cm} \times 5 \mathrm{~cm}$ ). These protectors were installed between February and April 2004, thus an unknown degree of browsing occurred between the fire and the establishment of these protectors. Only data corresponding to protected trees were used in the current study.

For the purposes of this comparative study, only data related to Fraxinus angustifolia (ash) and Quercus faginea (oak) resprouts are analysed, as these were the only species that were also planted in the area (see below). Both species had an excellent post-fire resprouting response (100\% of the trees in the case of ash and over 90\% for oak; Catry et al., 2006). The sample consisted of 19 ash and 56 oaks trees protected from herbivores. These were adult trees of ca. 5-15 m tall (mean diameter at breast height (DBH) of $35.3 \mathrm{~cm}$ ( range $=18.8-63.3 \mathrm{~cm}, n=48$ ) for oak; mean DBH of $33.3 \mathrm{~cm}$ (range $=20.7-50.9 \mathrm{~cm}, n=10$ ) for ash). The fire severity suffered by these trees was presumably high (charring height was on average $80 \%$ and $96 \%$ of total tree height, respectively for ash and oak, and the whole canopy was consumed by fire). Charred stems were logged after fire and remaining stumps (part of the trunk protruding from the ground after the tree has been felled) protected from herbivores. These stumps were assessed in June 2005, 21 months after fire. For each individual, the status (alive or dead, i.e. resprouting or not resprouting) and, for live trees, maximum shoot height (to the nearest $\mathrm{cm}$ ) and maximum shoot basal diameter (to the nearest $0.1 \mathrm{~cm}$, measured with a vernier caliper), were noted.

\subsection{Characterising survival and growth of planted trees}

Tree seedlings coming from nurseries were planted in 2004 (between January and March) and 2005 (mostly planted in January, but a few planted in December 2004). A sample of 122 trees that had been planted in the vicinity of the monitored transects was selected (30 ash and 30 oaks in 2004, and 29 ash and 33 oaks in 2005), all protected from herbivores with individual tree protections similar to the ones of resprouts. There was no information on seedling morphology when planted. However, for trees planted in 2004 measurements taken 1-3 months after planting, period during which growth must have been null or negligible, showed that mean height $( \pm$ S.E.) was $49.5 \pm 3.6 \mathrm{~cm}$ and $34.9 \pm 2.5 \mathrm{~cm}$, and basal diameter was $0.61 \pm 0.06 \mathrm{~cm}$ and $0.44 \pm 0.02 \mathrm{~cm}$, respectively for ash and oak. For 2005 we have no data on the size of planted seedlings.

To compare survival, height and diameter with resprouts, planted trees were also assessed 20-22 months after for trees planted in 2004, and 20 months after for trees planted in 2005. For each individual, we noted the status (dead or alive), basal diameter (to the nearest $0.1 \mathrm{~cm}$ ) and plant height (to the nearest $\mathrm{cm}$ ).

\subsection{Data analysis}

For each species, Fisher's exact tests were used to test if survival rate was independent of plant status (resprouting or planted, considering the 2 years of planting separately). Height and diameter were compared among resprouts and planted trees using the non-parametric Kruskal-Wallis and Mann-Whitney tests (Siegel and Castellan, 1988).

\section{Results}

Plant survival 20-22 months after fire/planting was higher in resprouts than in planted trees. This difference was significant for oak (98.2\% against $76.7 \%$ for 2004 , Fisher's exact test, $P=0.002$; and $66.7 \%$ for $2005, P<0.001)$ but not for ash $(100 \%$ against $86.7 \%$ in 2004 and $96.6 \%$ in 2005) (respectively, $P=0.148$ and $P=1.00$ ) (Fig. 1). For planted trees, differences between the 2 years were not statistically significant (Fisher's exact test, $P=0.353$ and $P=0.416$, respectively for ash and oak).

Plant height 20-22 months was significantly higher in ash resprouts (median $=208.0 \mathrm{~cm}, n=19$ ) than in trees planted in 2004 (median $=53.0 \mathrm{~cm}, n=26$ ) and 2005 (median $=108.5 \mathrm{~cm}, n=28$ ) (K-W test; $\chi^{2}=53.2, P<0.001$ ) (Fig. 2). For planted trees, differences between the 2 years were also significant (Mann-Whitney test, $Z=4.79, P<0.001)$. A similar pattern was found for oak, with resprouts (median $=180.0 \mathrm{~cm}, n=55$ ) being much taller than individuals planted in 2004 (median $=37.0 \mathrm{~cm}, n=23$ ) and 2005 (median $=47.0 \mathrm{~cm}, n=22)\left(\mathrm{K}-\mathrm{W}\right.$ test; $\left.\chi^{2}=69.4, P<0.001\right)$ (Fig. 2$)$. 


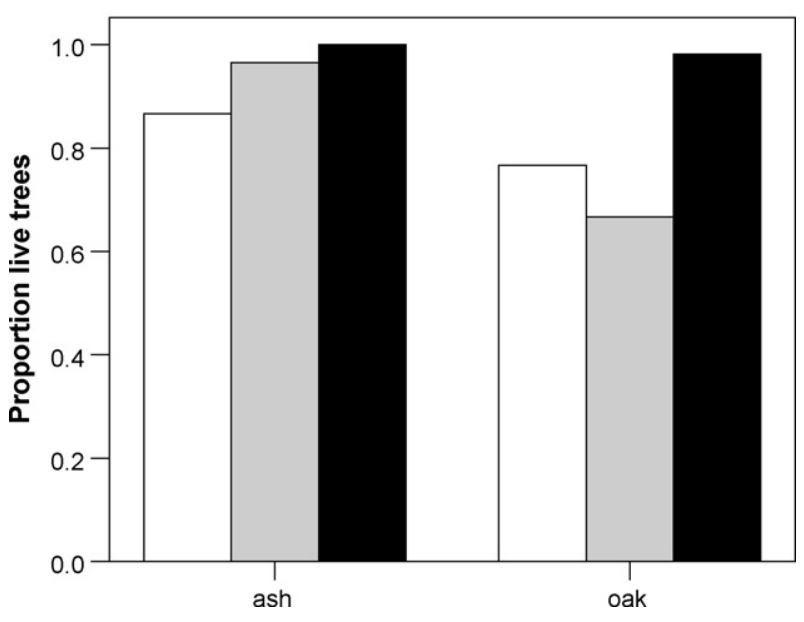

Fig. 1. Survival of planted seedlings (white bars: trees planted in 2004; grey bars: trees planted in 2005) and post-fire resprouts (black bars) for ash and oak, after 20-22 months of growing period.
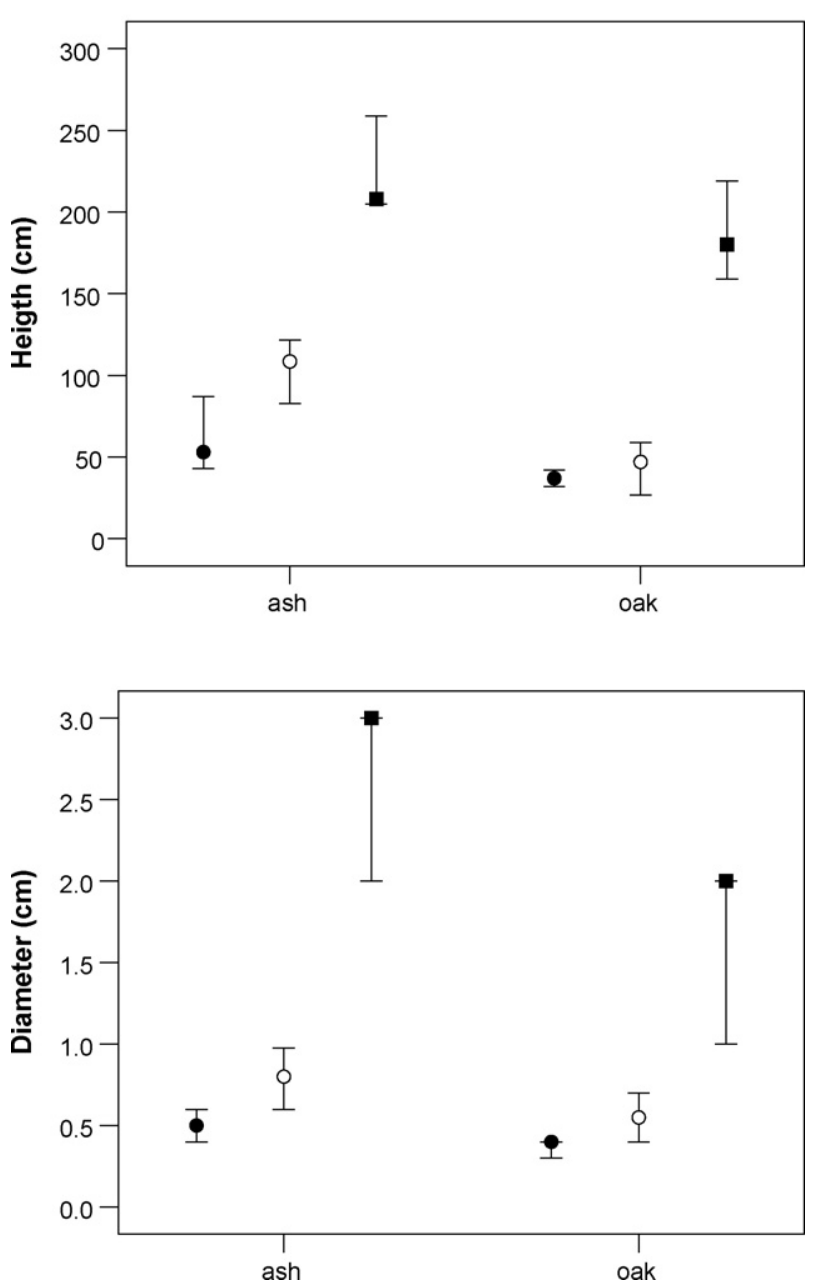

Fig. 2. Median and inter-quartile range (25\% and $75 \%$ percentiles) of maximum plant height and stem diameter for ash and oak, after 20-22 months of growing period. Values are given for seedlings planted in 2004 (black dots), planted in 2005 (white dots), and post-fire resprouts (black squares).
For planted trees, differences between the 2 years were not significant (Mann-Whitney test, $Z=1.39, P=0.162$ ).

Stem basal diameter after 20-22 months was significantly higher in ash resprouts (median $=3.00 \mathrm{~cm}$ ) than in trees planted in $2004($ median $=0.50 \mathrm{~cm})$ and $2005($ median $=0.80 \mathrm{~cm})(\mathrm{K}-\mathrm{W}$ test; $\chi^{2}=46.9, P<0.001$ ) (Fig. 2). For planted trees, differences between the 2 years were also significant (Mann-Whitney test, $Z=3.95$, $P<0.001)$. Similarly for oak, resprout diameter $($ median $=2.0 \mathrm{~cm})$ was much thicker than in trees planted in 2004 (median $=0.40 \mathrm{~cm})$ and 2005 (median $=0.55 \mathrm{~cm})\left(\mathrm{K}-\mathrm{W}\right.$ test; $\left.\chi^{2}=68.5, P<0.001\right)$ (Fig. 2 ). For planted trees, differences between the 2 years were also significant (Mann-Whitney test, $Z=2.84, P=0.005$ ).

\section{Discussion}

Passive forest restoration techniques are a valid approach when ecosystem structural/functional damage is limited and resilience is high (Lamb and Gilmour, 2003; Vallejo et al., 2006). However, even when natural regeneration is expected to occur and constitutes a viable option, post-fire restoration projects in the Mediterranean basin often do not consider this alternative, concentrating efforts only in active restoration techniques (which can even destroy natural regeneration while being implemented). In fact, from a political perspective, there has been a simplistic approach of comparing areas burned and actively reforested (Pausas et al., 2004a,b).

This study provided evidence that taking advantage of basal resprouting may be a suitable alternative strategy to replanting ash and Portuguese oak in central Portugal, as the survival and size of resprouts were higher, at least in the early stages of tree growth. Other studies have shown that the management of resprouting is a powerful technique to restore Mediterranean oak forests (Espelta et al., 2003), and this may hold for most Mediterranean areas and tree species, as long as they are resprouters (thus, most broadleaves). In our study area, 8 out of 11 tree species showed resprouting behaviour after fire, the only exceptions being pines (Catry et al., 2006). However, the fact that this study did not follow a strict experimental design but was constrained to the monitoring of reforestation actions taken by the managers of the study area brings some degree of uncertainty to the obtained results. For example, trees were planted in two consecutive years, rather than in the same year. The size of seedlings at the time of planting could not be assessed. Planting dates did not coincide with the timing of the wildfire. On the other hand, for resprouting trees, individual tree protectors were installed only 2-4 months after fire, thus an unknown degree of browsing probably had negative effects on sprout growth. Finally, resprouts were assessed just before summer (in June) whereas seedlings were assessed a few months latter (August and September), after the dry summer period. Although these drawbacks should be taken into account when interpreting these results, the differences between survival and, in particular, size of sprouts and planted trees bring some degree of evidence to the advantages of using the resprouting characteristics of trees as a tool in post-fire restoration. This could be expected from an ecological point of view, as sprouts of adult trees should have a well established root system that enables higher survival and plant growth when compared to the very young trees coming from nurseries. But few studies have quantified these differences and in fact in many Mediterranean areas the political response to forest fires still is promoting reforestation actions, rather than managing resprouting.

There are several advantages of using resprouting for restoration. First of all, the costs are lower, as less heavy or no equipment is needed, and often site preparation is not required (Duyea, 2000; Lamb and Gilmour, 2003; Whisenant, 2005). Soil mobilization and subsequent erosion risk are also minimised. Plant survival and growth are enhanced as the resprouts have a well established root 
system, and a subsequent faster vegetation cover is achieved, again with important implications for preventing soil erosion (Vallejo et al., 2006). Further stages in natural regeneration management, depending on the objectives, may involve thinning, the selection of shoots and the control of unwanted vegetation (Lamb and Gilmour, 2003; Holz and Placci, 2005; Whisenant, 2005), and these will have associated costs. In contrast, planting has some drawbacks, most noticeably the costs associated with the acquisition of plant seedlings from nurseries, transport to the area (particularly in areas where access is difficult), fertilizers, tree shelters, replacement of dead plants, and human labour. Finally, plant survival and growth rates are generally much lower, particularly in the case of hardwoods (Duyea, 2000; Lamb and Gilmour, 2003; Whisenant, 2005). In the current study survival of planted seedlings was particularly good when compared with other studies (Pausas et al., 2004b; Vallejo et al., 2006), in part because there was a particularly careful selection of sites for plantations.

Differences between seedling survival and size after 20-22 months of planting were obvious for individuals planted in 2004 and 2005. This could be due to either or both (a) different seedling qualities used in the 2 years, and (b) the better climatic conditions (more rainfall) experienced by individuals planted in 2005, compared to the ones planted in 2004 (which have experienced two consecutive very dry years).

In conclusion, the fact that Mediterranean-type ecosystems are often dominated by shrub and tree species that have the ability to resprout after fire (e.g. Pausas, 1999) confers a high resilience to these systems. This characteristic could be used in post-fire restoration, mainly through assisting natural regeneration that will likely result in higher survival and growth rates, and thus a faster recovery rate, and generally less costly technical interventions, when compared to planting. However, further comparative studies of planted trees and resprouting individuals, using more appropriate experimental designs and controlled experiments, should be carried out to confirm the generality of the findings of this study and assess longer-term differences in survival and growth.

\section{Acknowledgements}

The present study was funded by Fundação para a Ciência e a Tecnologia (project POCI/AGR/61407/2004) and Fundo Florestal Permanente (Projecto Recuperação de áreas ardidas). Thanks are due to Marjorie Kauffman, Ana Santos and Ricardo Silva for help during fieldwork. We also would like to acknowledge to the Tapada Nacional de Mafra administration and personnel for their logistic support.

\section{References}

Amil, M.L., 2007. Forest fires in Galicia (Spain): threats and challenges for the future. J. Forest Econ. 13, 1-5.

Ammer, C., Mosland, R., 2007. Which grow better under the canopy of Norway spruce-planted or sown seedlings of European beech? Forestry 80, 385395.

Bond, W.J., van Wilgen, B.W., 1996. Fire and Plants. Chapman and Hall, London.

Carvalho Mendes, A., 2006. Implementation analysis of forest programmes: some theoretical notes and an example. Forest Policy Econ. 8, 512-528.

Catry, F.X., Rego, F.C., Bugalho, M.N., Lopes, T., Silva, J.S., Moreira, F., 2006. Effects of fire on tree survival and regeneration in a Mediterranean ecosystem. In: Viegas, D.X. (Ed.), Proceedings of the 5th International Conference on Forest Fire Research. ADAI, Figueira da Foz, CD Rom (5 pp.).

Dostálek, J., Weber, M., Matula, S., Frantík, T., 2007. Forest stand restoration in the agricultural landscape: the effect of different methods of planting establishment. Ecol. Eng. 29, 77-86.

Duyea, M.L., 2000. Forest Regeneration Methods: Natural Regeneration, Direct Seeding and Planting. Circular 759. Florida Cooperative Extension Service, Institute of Food and Agricultural Sciences, University of Florida.

Espelta, J.M., Retana, J., Habrouk, A., 2003. Resprouting patterns after fire and response to stool cleaning of two coexisting Mediterranean oaks with contrasting leaf habits on two different sites. Forest Ecol. Manag. 179, 401-414.

Holz, S., Placci, G., 2005. Stimulating natural regeneration. In: Mansourian, S., Vallauri, D., Dudley, N. (Eds. in cooperation with WWF International), Forest Restoration in Landscapes. Beyond Planting Trees. Springer, New York, pp. 250-256.

Hüttl, R.F., Gerwin, W., 2007. Forest rehabilitation after disturbance. Ecol. Eng. 31, 145-146.

Lamb, D., Gilmour, D., 2003. Rehabilitation and Restoration of Degraded Forests. IUCN, Gland, Switzerland and Cambridge, UK and WWF, Gland, Switzerland.

Lockhart, B.R., Keeland, B., McCoy, J., Dean, T., 2003. Comparing regeneration techniques for afforesting previously farmed bottomland hardwood sites in the lower Mississippi alluvial valley, USA. Forestry 76, 169-180.

Pausas, J.G., 1999. Mediterranean vegetation dynamics: modelling problems and functional types. Plant Ecol. 140, 27-39.

Pausas, J.G., Ribeiro, E., Vallejo, R., 2004a. Post-fire regeneration variability of Pinus halepensis in the eastern Iberian Península. Forest Ecol. Manag. 203, 251259.

Pausas, J.G., Bladé, C., Valdecantos, A., Seva, J.P., Fuentes, D., Alloza, J.A., Vilagrosa, A., Bautista, S., Cortina, J., Vallejo, R., 2004b. Pines and oaks in the restoration of Mediterranean landscapes of Spain: new perspectives for an old practice-a review. Plant Ecol. 171, 209-220.

Siegel, S., Castellan Jr., N.J., 1988. Nonparametric Statistics for the Behavioural Sciences. McGraw-Hill, New York, NY, USA.

Simões, C., Marques, M., 2007. The role of sprouts in the restoration of Atlantic rainforest in Southern Brazil. Restor. Ecol. 15, 53-59.

Vallejo, R., 2005. Restoring Mediterranean forests. In: Mansourian, S., Vallauri, D., Dudley, N. (Eds. in cooperation with WWF International), Forest Restoration in Landscapes. Beyond Planting Trees. Springer, New York, pp. 313-319.

Vallejo, R., Aronson, J., Pausas, J., Cortina, J., 2006. Restoration of Mediterranean woodlands. In: van Andel, J., Aronson, J. (Eds.), Restoration Ecology: The New Frontier. Blackwell Science, Oxford, UK, pp. 193-207.

Whisenant, S., 2005. Managing and directing natural succession. In: Mansourian, S., Vallauri, D., Dudley, N. (Eds in cooperation with WWF International), Forest Restoration in Landscapes. Beyond Planting Trees. Springer, New York, pp. 257-261.

Wyant, J.G., Meganck, R.A., Ham, S.H., 1995. The need for an environmental restoration decision framework. Ecol. Eng. 5, 417-420. 